\title{
EVALUATING THE ROLE OF IL-2 AND IL-6 IN PATIENTS WITH BURNS USING ELISA TECHNIQUE
}

\author{
Sarah Naji Aziz ${ }^{{ }^{*}}$, Rana Naji Aziz ${ }^{2}$, Karrar Jasim Al-Sallami ${ }^{1}$, Ali Naji Aziz ${ }^{3,4}$ Walaa Abdulsahib \\ Mikaeel ${ }^{4}$, Noor Jameel Mousa ${ }^{1}$, Sundus Qasim Mohammed ${ }^{1}$ \\ ${ }^{1}$ College of Science, Mustansiryiah University, Baghdad, Iraq \\ ${ }^{2}$ College of Tourism Sciences, Mustansiryiah University, Baghdad, Iraq \\ ${ }^{3}$ Al- Rafidain educational dental clinics, Baghdad, Iraq \\ ${ }^{4}$ Ministry of Health, Baghdad, Iraq \\ ${ }^{*}$ Corresponding author. sarahnaji2015@gmail.com
}

\begin{abstract}
Introduction: Burns are common medical infections that examined in hospitals. Cytokines are produced by innate immune response; cytokines determine the type of adaptive immune response. This study aims to screen and evaluate the role of IL-2 and IL-6 levels in the serum of patients who have suffered from burns by ELISA technique. Methods: Seventy serum samples were collected from burned patients in Baghdad city hospitals and tested by ELISA technique to detect IL-2 and IL-6 levels. Results: Shows great differences in IL-2 level of male patients $(30.16 \mathrm{pg} / \mathrm{ml})$ compared to males control group by an average of $(29.66 \mathrm{pg} / \mathrm{ml})$. While IL-6 shows significant differences in female patients with range $(63.39 \mathrm{pg} / \mathrm{ml})$ and male $(66.47 \mathrm{pg} / \mathrm{ml})$ compared to females control group $(2.48 \mathrm{pg} / \mathrm{ml})$ and males $(22.80 \mathrm{pg} / \mathrm{ml})$. Moreover cytokines shows significant differences between the three age groups of burned patients in comparison with the control group. In conclusion the result of present study showed significant difference in level of some cytokines IL-2,IL-6 for patients with burns. Conclusion: the result of present study showed significant difference in level of some cytokines IL-2, IL-6 for patients with burns.
\end{abstract}

Keywords: Cytokines, inflammatory response, IL-2, IL-6, ELISA 


\section{Introduction}

It is known that burns are one of the most common medical infections which are examined in hospitals and clinics. Burns occur as a result of exposing the skin to higher temperatures whether by liquids, solid objects or by direct exposure to flames, chemicals and electrical touches (Kaddoura et al., 2017). Skin and mucous membranes are considered as the first line of defense in immune system against infection and the loss of these barriers leads to the suppression of general immunity in the body which paves the entry of pathogenic microorganisms at the site of the burn, the body's immune system initiates an inflammatory response in the area of infection (Chen et al., 2018). Interleukins function is stimulating and regulating the cellular and humoral immune response. Interleukin 2 (IL-2 )secreted from T-Helper (Th1), while Interleukin 6 (IL-6) secreted from (Th2), monocytes, bone marrow and mast cells play an important role in differentiating B-cells into plasma cells that produce antibodies, (Al-Khafaji, Al-Mosawi, and Al-Saeedi, 2015), as well as stimulating acute phase proteins produced by liver cells (Finnerty et al., 2007). The defense against microorganisms or intracellular microbes is called cell-mediated immunity, which is caused by T-cells, while B-cells are responsible for antibodies production. Cytokines are produced by innate immune response, it determines the type of adaptive immune response (Steven and Vera 2000). This study aims to screen and evaluate the role of IL- 2 and IL- 6 levels in the serum of patients suffered from burns by ELISA technique.

\section{Methods}

Total of seventy serum samples were collected from patients suffering from burns, between November 2017 and March 2018 from several hospitals in Baghdad - Iraq. The samples were from both male and females in a range of age between 1-55 years old. $5 \mathrm{~mm}$ of venous blood were collected in plane tubes and left for a while at room temperature for clotting. Centrifugation had done at $3000 \mathrm{rpm}$ for $10 \mathrm{~min}$, to separate the serum. After that serum had been moved in plane tubes and Serums were kept at $20^{\circ} \mathrm{C}$ to the next tests.

\section{Screening for Interleukin-2}

Tests were done according to the principle of testing that is mentioned in (Bodas et al., 2006). The immunoassay technique for adsorbed quantitative enzyme were done, IL-2 antibodies were previously encapsulated with a microplate, standards and specimens were dispersed by a fine pipette in the wells. After removing unrelated substances, the biotin that conjugated with IL-2 antibody was added to the wells. Avidin reagent were added and bended with Horseradish Peroxidase (HRP) enzyme in wells. After washing to remove avidin reagent, substrate was added to the wells and the color density is measured (Kiecolt-Glaser \& Glaser 2002). Each well was filled with $100 \mu$ of substrate and the samples, procedure was done according to the leaflet of Manufacture Company. The optical density was measured by using ELISA reader at $450 \mathrm{~nm}$ as showed in figure (1) (Kiecolt-Glaser \& Glaser 2002).

\section{Screening for Interleukin-6}

As mentioned above, (Bodas et al., 2006) is used as the main principle of testing. Microtiter plate in this diagnostic kit was covered with IL6 specific antibodies. Standards samples were then added to the appropriate standard plate. The polyclonal biotin coupled with the specific IL-6 antibodies and the avidin reagent that bended with Horseradish Peroxidase (HRP) enzyme for each well in the microscopic plate and incubated. TMB (3,3 ', 5,5' dimethylbenzidine) solution is then added to the wells. Only wells that contained IL-6, biotin were coupled with antibodies and avidin coupled with HRP will show a change in color. The enzyme reaction of the base enzyme is terminated by the addition of a sulfuric acid solution and color change spectrometry was measured by using ELISA reader at $450 \mathrm{~nm}$ (Kiecolt-Glaser \& Glaser 2002).

\section{Statistical analysis}

All statistical analyses were calculated using Minitab software version 6 for data analyzing. $P$ value was done also to compare means between groups in this study. $P$ value equal or less than 0.05 was considered as the level of statistical significance. 


\section{Ethical statement}

All samples which included human serum from Baghdad hospitals were ethically approved according to the ethics committees in Ministry of Health, Baghdad, Iraq. Tests which included ELISA assay were done according to biosafety conditions in Biology department - College of Science / Mustansiryiah University - Iraq.

\section{Results}

Results show that the samples of patients that included a total of seventy samples of serum, $33(47.14 \%)$ female and $37(52.85 \%)$ male while control group were ten, $5(50 \%)$ female

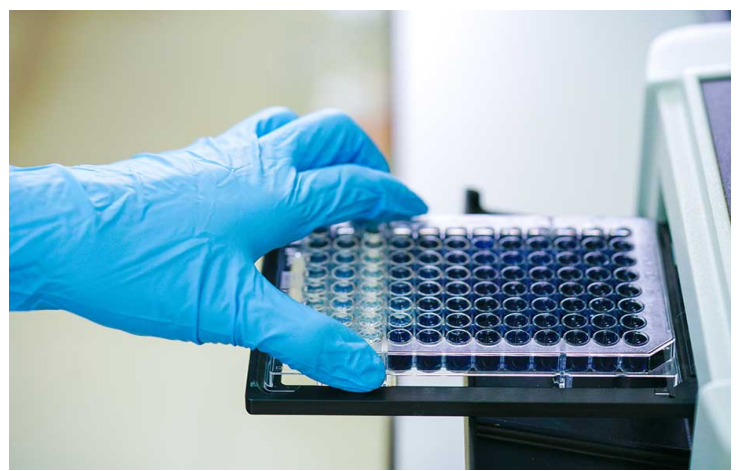

and $5(50 \%)$ male with different ages cleared in table(2).

Results show insignificant increase in the level of IL-2 between male and female who were infected with burn in comparison with control group. Highest levels in females and males with burns were $18.22 \mathrm{pg} / \mathrm{ml}$ and $29.64 \mathrm{pg} / \mathrm{ml}$ respectively, while control group for females and males were about $15.03 \mathrm{pg} / \mathrm{ml}$ and 18.48 $\mathrm{pg} / \mathrm{ml}$ respectively. However, significant increase is revealed in the level of IL-6 in females and male were about $63.39 \mathrm{pg} / \mathrm{ml}$ and $66.47 \mathrm{pg} / \mathrm{ml}$ respectively, while the control group for females and males in IL-6 were about $2.48 \mathrm{pg} / \mathrm{ml}$ and $22.70 \mathrm{pg} / \mathrm{ml}$ respectively as showed in Table.2.

Figure 1: ELISA reader for measuring the samples optical density

Table 1: Distribution of study groups by sex

\begin{tabular}{|c|c|c|c|c|}
\hline \multirow{2}{*}{ Gender } & \multicolumn{2}{|c|}{ Burned infected group } & \multicolumn{2}{c|}{ Control Group } \\
\cline { 2 - 5 } & $\mathrm{N}$ & $\%$ & $\mathrm{~N}$ & $\%$ \\
\hline Female & 33 & 47.14 & 5 & 50 \\
\hline Male & 37 & 52.85 & 5 & 50 \\
\hline Total No. & 70 & 100 & 10 & 100 \\
\hline
\end{tabular}

Table 2: Distribution IL-2 and IL-6 levels in burned and control groups according to the gender

\begin{tabular}{|c|c|c|c|c|c|c|}
\hline \multicolumn{4}{|c|}{ IL-2 } & \multirow[b]{2}{*}{ P-value } & \multirow{2}{*}{$\begin{array}{c}\text { P-value } \\
\text { between } \\
\text { female in } \\
\text { both groups }\end{array}$} & \multirow{2}{*}{$\begin{array}{c}\text { P-value } \\
\text { between } \\
\text { male in both } \\
\text { groups }\end{array}$} \\
\hline Groups & Gender & Average & Number & & & \\
\hline \multirow{2}{*}{$\begin{array}{c}\text { Bourn } \\
\text { infected } \\
\text { group }\end{array}$} & Female & 18.22 & 33 & & \multirow{4}{*}{0.242} & \multirow{4}{*}{0.014} \\
\hline & Male & 29.64 & 37 & 0.242 & & \\
\hline \multirow{2}{*}{$\begin{array}{l}\text { Control } \\
\text { Group }\end{array}$} & Female & 15.03 & 5 & \multirow[t]{2}{*}{0.354} & & \\
\hline & Male & 18.48 & 5 & & & \\
\hline \multicolumn{4}{|c|}{ IL-6 } & & & \\
\hline \multirow{2}{*}{$\begin{array}{c}\text { Bourn } \\
\text { infected } \\
\text { group }\end{array}$} & Female & 63.39 & 33 & \multirow[b]{2}{*}{0.366} & \multirow{4}{*}{0.001} & \multirow{4}{*}{0.004} \\
\hline & Male & 66.47 & 37 & & & \\
\hline \multirow{2}{*}{$\begin{array}{l}\text { Control } \\
\text { Group }\end{array}$} & Female & 2.48 & 5 & \multirow[t]{2}{*}{0.014} & & \\
\hline & Male & 22.80 & 5 & & & \\
\hline
\end{tabular}




\section{Discussion}

The results of our present study are agreement with the previous study of (Gauglitz et al., 2008) by conducting an evaluation of some interleukins in a group of males and females with different types and degrees of burns where they show a significant increase between the levels of interleukins in people with burns. The inflammatory response to the cells of the immune system and especially $T$ lymphocytes and their production of these interleukins, which are key factors in determining the strength of the immune response. The high level of IL-6 cellular motility is due to the stimulation of immune system cells such as helper Tlymphocytes, monocytes, bone marrow and mast cells because of burned infections that stimulate these immunological cells. The previous study of (Pileri et al., 2008), found that cytokines in patients with burned cases in both ganders were increased significantly with increasing in inflammatory processes.

(Gosain \& Gamelli. 2005), who studied the effect of levels of some cytokines, including IL2 , on different age stages of burn-affected people, showed that the increasing of these interleukins is the result of activation of $\mathrm{T} 1$ lymphocytes that play an important role in the inflammatory response of the immune system by forming a series of Interleukins, including IL2 , which in turn affect other cells such as stimulating the toxicity of immune cells, from the above study, the results of our study converge or similar to the results of that study.

While in another study (Maass et al., 2002), it is found that the high levels of immune index in IL6 within the first stages of age is due to the degree of burning of the infected person and the response of the immune system to the inflammatory process and stimulation of the $\mathrm{T}$ lymphocytes (Th2) responsible for the rise of these interleukins and this is consistency with the results of our current study. As a final result, this study manifests significant changes in the levels of interleukins IL-2 and IL-6 in burn patients.

\section{Conclusions:}

This study reveals that interleukins, in different age stages of burn-affected people, will be increased in levels and this increasing happens due to the activation of T1 lymphocytes that play a tremendous role in the inflammatory response of the immune system. As a final result. This study shows significant changes in the levels of motor cytokines IL-2 and IL- 6 in burn patients.

\section{References}

Al-Khafaji, J. K.; Al-Mosawi, M.A. and AlSaeedi, A. K. (2015). Serum level of IL-2, IgG and IgM in Treated and Untreated TB Patents. Advances in Environmental Biology. 9(27), 8589

Bodas, M.; Jain, N.; Awasthi, A.; Martin, S.; Loka, R. K. P.; Dandekar, D.; Mitra, D. and Saha, B. (2006) Inhibition of IL-2 Induced IL-10 Production as a Principle of Phase-Specific Immunotherapy. J. Immunol, 177 (7), 46364643 doi.org/10.4049/jimmunol.177.7.4636

Chen, L. ; Deng, H. ; Cui, H. ; Fang, J. ; Zuo, Z.; Deng, J.; Wang, X. and Zhao, L. (2018) Inflammatory responses and inflammationassociated diseases in organs. Oncotarget 9(6), 7204-7218 doi: 10.18632/oncotarget.23208

Gauglitz, G. G. ; Song, J. ; Herndon, D. N. ; Finnerty, C. C.; Darren, B.; Jose, M. and Marc, G. (2008). Characterization of the inflammatory response during acute and post-acute phases after severe burn. Shock, 30(5) 503-507 doi: 10.1097/SHK.0b013e31816e3373

Gosain, A. and Gamelli, R. L. (2005) A primer in cytokines. J. Burn Care Rehabil, 26: 7-12 DOI: 10.1097/01.BCR.0000150214.72984.44

Kaddoura, I. ; Abu-Sittah, G. ;_Ibrahim, A. ; Karamanoukian R. and Papazian , N. (2017) Burn injury: review of pathophysiology and therapeutic modalities in major burns. Annals of Burns and Fire Disasters 30(2), 95-102. PMID: 29021720

Kiecolt, J. K. and Glaser, R. (2002) Depression and immune function central pathway to morbidity and mortality. J. Psychosom Res., 53: 873-876 https://doi.org/10.1016/S00223999(02)00309-4

Maass, D. L.; White, J. and Horton, J. W. (2002). IL-1 $ß$ and IL-6 act synergistically with TNFa to alter cardic contractile function after burn trauma. Shock, 18 360-366 PMID: 12392281 
Pileri, D.; Accardo, P.A.; D’Amelio, L.; D'Arpa, N.; Amato, G.; Masellis, A.; Cataldo, V.; Mogavero, R.; Napoli, B.; Lombardo, C. and Conte, C. (2008) Concentrations of cytokines IL-6 and IL-10 in plasma of burn patients: their relationship to sepsis and outcome. Ann. of
Burns and Fire Disasters, 21(4) 182-185 PMID: 21991134

Steven, M. Opal. ; Vera, A. D. (2000) AntiInflammatory Cytokines. Chest. Elsevier, 117 (4) doi.org/10.1378/chest.117.4.1162 